\title{
Two or More New Bone Lesions Indicator
}

National Cancer Institute

\section{Source}

National Cancer Institute. Two or More New Bone Lesions Indicator. NCI Thesaurus.

Code C132490.

An indication as to whether there are two or more bone tumors that have not been previously seen or characterized. 